\title{
Managing reputational risk during supply chain disruption recovery: A triadic logistics outsourcing perspective
}

\begin{tabular}{|c|c|}
\hline \multicolumn{2}{|c|}{$\begin{array}{l}\text { Authors: } \\
\text { Tanja Blom }{ }^{1} \\
\text { Wesley Niemann }^{1}\end{array}$} \\
\hline \multicolumn{2}{|c|}{$\begin{array}{l}\text { Affiliations: } \\
\text { }{ }^{1} \text { Department of Business } \\
\text { Management, Faculty of } \\
\text { Economic and Management } \\
\text { Sciences, University of } \\
\text { Pretoria, Pretoria, } \\
\text { South Africa }\end{array}$} \\
\hline \multicolumn{2}{|c|}{$\begin{array}{l}\text { Corresponding author: } \\
\text { Wesley Niemann, } \\
\text { wesley.niemann@up.ac.za }\end{array}$} \\
\hline \multicolumn{2}{|c|}{$\begin{array}{l}\text { Dates: } \\
\text { Received: } 09 \text { June } 2021 \\
\text { Accepted: } 27 \text { Nov. } 2021 \\
\text { Published: } 31 \text { Jan. } 2022\end{array}$} \\
\hline \multicolumn{2}{|c|}{$\begin{array}{l}\text { How to cite this article: } \\
\text { Blom, T. \& Niemann, W., } \\
\text { 2022, 'Managing reputational } \\
\text { risk during supply chain } \\
\text { disruption recovery: A triadic } \\
\text { logistics outsourcing } \\
\text { perspective', Journal of } \\
\text { Transport and Supply Chain } \\
\text { Management } 16(0), \text { a623. } \\
\text { https://doi.org/10.4102/ } \\
\text { jtscm.v16i0.623 }\end{array}$} \\
\hline \multicolumn{2}{|c|}{$\begin{array}{l}\text { Copyright: } \\
\text { (C) 2022. The Authors. } \\
\text { Licensee: AOSIS. This wa } \\
\text { is licensed under the } \\
\text { Creative Commons } \\
\text { Attribution License. }\end{array}$} \\
\hline \multicolumn{2}{|l|}{ Read online: } \\
\hline 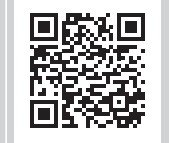 & $\begin{array}{l}\text { Scan this QR } \\
\text { code with your } \\
\text { smart phone or } \\
\text { mobile device } \\
\text { to read online. }\end{array}$ \\
\hline
\end{tabular}

Background: The coronavirus disease 2019 (COVID-19) pandemic has opened the world's eyes to the impact that supply chain disruptions have on our society. Supply chain disruptions can result in various long-term effects, of which reputational risk is one of the biggest. A good reputation can create value for all stakeholders of a firm, however it can also expose a firm to risk. Reputational risk has been extensively studied in supply chain management; however, the management of reputational risk during supply chain disruption recovery (SCDR) has been neglected.

Objective: This study explores reputational risk management during SCDR, between a logistics triad consisting of third party logistics providers (3PLs), their upstream suppliers and downstream customers within a South African context.

Method: A generic qualitative design was employed to collect data from five logistics triads using semi-structured interviews.

Results: The study found that reputational risk has a predominantly positive influence on the SCDR process. Furthermore, the study expands on existing literature by identifying additional approaches to manage corporate reputation during SCDR not evident in literature. These approaches include the use of control centres and involvement of the key account manager.

Conclusion: This study creates awareness for the importance of reputational risk during SCDR and also provides managers with valuable insight into how reputational risk should be managed during SCDR.

Keywords: reputational risk; disruption recovery; 3PLs; triadic perspective; generic qualitative design; South Africa.

\section{Introduction}

Recent global events such as the coronavirus disease 2019 (COVID-19) pandemic, terrorist attacks, high-impact political affairs such as the United Kingdom's (UK) Brexit and the trade wars between China and the United States of America (US) have emphasised the vulnerability of supply chains (Cohen \& Kupferschmidt 2020:963; Gerschel, Martinez \& Mejean 2020:7; Sáenz, Revilla \& Acero 2018:2). The vulnerability of supply chains does not only stem from external events, but can also originate internally within a firm, that is, labour unrest and information systems downtime (Baghersad 2018:4; Nel et al. 2018:7). These events may lead to supply chain disruptions (SCDs), which are occurrences that disrupt the standard flow of goods and generate various short- and long-term risks to the supply chain (DuHadway, Carnovale \& Hazen 2019:180; He et al. 2019:134). Financial losses are seen as the main risk caused by SCDs, however firms also experience substantial reputational damage as a result of SCDs (Elluru et al. 2019:199; Mithun Ali \& Nakade 2014:88).

The Business Continuity Institute reports that $31.2 \%$ of firms experienced damage to their reputation and image as a consequence of SCDs that occurred within the firm's supply chains (BCI 2019:30). This reputational risk is the manifestation of events resulting from negative reactions by stakeholders, which have the possibility to harm the firm's image and ultimately lead to a decline in the customer base or lost profit potential (Galuchi, Rosales \& Batalha 2019:158). A good reputation can create value for all stakeholders of a firm; however it can also expose a firm to reputational risk as the expectations by stakeholders of a firm with a good reputation are higher than towards a firm with a bad reputation (Morgan 2018:1; Szwajca 2018:165-166). 
Supply chains are increasingly advancing into extended networks, where network partners are becoming more dependent on each other (Kamalahmadi \& Parast 2016:116; Sanchez Rodrigues, Harris \& Mason 2015:631). This interconnectedness indicates a mutual dependency on the behaviours and efforts of one another (Horn et al. 2015:193). If one network partner acts in an adverse manner, the other network partners' reputations may be placed at risk (Petersen \& Lemke 2015:495). This behaviour can be demonstrated in the network of third party logistics providers (3PLs), their upstream suppliers and downstream customers. The 3PLs provide various logistical services, such as transportation and storage of goods for their clients (Akman \& Baynal 2014:3; Grant et al. 2014:214). They take on multiple roles in the supply chain, which vary from simple outsourcing contractors to more progressive roles such as integrators and orchestrators within focal firms' supply chains (Azad, Dhayanidhi \& Narashiman 2011:34).

The outsourcing of logistical services may expose firms to various SCDs (Nel et al. 2018:10). These SCDs can lead to unmet expectations that have the potential to create a bad reputation for the 3PL with regard to poor logistics performance (Alfarsi, Lemke \& Yang 2019:1528). A good reputation has been identified as an approach to mitigate the negative consequences of an SCD (Lemke \& Petersen 2013:414; Vanhamme \& Grobben 2009:273). As stakeholders find reputational risk to be the greatest challenge to contemporary firms, further research in this field is considered as valuable (Szwajca 2018:166)

\section{Problem statement}

Previous studies have investigated risks, such as macroenvironmental risks (Tukamuhabwa et al. 2015:5593), supply and demand risks (He 2013:541) and process risks (Samvedi, Jain \& Chan 2013:2435). However, reputational risk is one of the biggest supply chain risks that has been overlooked, as reputational risk is not directly disruptive to resources (Lemke \& Petersen 2013:413; Tannous \& Yoon 2018:193).

Whilst many researchers have studied reputational risk from the perspective of external stakeholders such as the firm's customers, only a few have explored reputational risk from the perspective of a firm's upstream suppliers and downstream customers (Rebs et al. 2018:197). To encapsulate this perspective, it is suggested that a logistics triad model is followed. This will enable researchers to gain a holistic perspective of the logistics triad's interactions with one another (Stefansson 2006:77; Wikner \& Bäckstrand 2018:6). The logistics triad consists of a goods buyer, a goods supplier and a 3PL (Larson \& Gammelgaard 2001:204). This study centres its focus on 3PLs, as there is a high probability of SCDs occurring during the outsourcing of logistical services (Klibi, Martel \& Guitouni 2010:287). The 3PLs are also known to play a significant role in implementing effective supply chain risk management initiatives, emphasising the need to use 3PLs as the focus point of the research (Meyer et al. 2019:2). The 3PLs are known to operate in various industries, such as the fast-moving consumer goods (FMCG) industry, the automotive industry, the manufacturing industry and the retail industry (Foulds 2013:32). These industries experience distinct SCDs and risks (Oke \& Gopalakrishnan 2009:171-174). Furthermore, South African firms are known to be more vulnerable and susceptible to SCDs as South Africa is a developing country (Essers 2013:63; Gereffi \& Luo 2015:56). The scope of supply chain risk management literature conducted in developing countries is limited when compared with the research conducted in developed countries (Prakash, Soni \& Rathore 2017:78).

Reputational risk has been studied in various elements of supply chain management, such as sustainable supply chain management (Roehrich, Grosvold \& Hoejmose 2014:695-719), supply chain risk management (Gaudenzi, Confente \& Christopher 2015:248-260) and educational practices in supply chain (Lemke \& Petersen 2013:413-428). However, as far as could be determined, no studies exploring reputational risk in supply chain disruption recovery (SCDR) have been conducted.

This generic qualitative study explores reputational risk management during SCDR, between a logistics triad consisting of 3PLs, their upstream suppliers and downstream customers within a South African context. In particular, the study attempts to determine which approaches the logistics triad use to manage reputational risk during SCDR. Furthermore, the study also investigates what influence reputational risk has on the SCDR process. Data were collected through semi-structured interviews with senior managers of 3PLs operating in South Africa, their upstream suppliers and downstream customers across five industries.

This study was guided by the following two research questions:

- How do logistics triads manage reputational risk during SCDR?

- How does reputational risk influence the SCDR process between members of a logistics triad?

The contribution of this study is twofold. First, the study expands on existing literature by identifying various approaches to manage reputational risk in an SCDR context. Managers can now actively manage the reputational risk that occurs in the SCDR process by having pre-determined, suggested approaches in place. This may be valuable to managers as it would ultimately enable a more effective SCDR process. Second, this study brings awareness of the importance of managing reputational risk during SCDR, as it could result in great benefits if managed properly and conversely could result in lasting negative consequences when not managed at all.

The remainder of this article is structured as follows. First, an extensive review of current literature is conducted. Second, the methodology used in the study is outlined. Thereafter, the findings of the study are presented and a conclusion is drawn. 
Finally, the study's potential managerial and theoretical implications are outlined followed by the limitations of the study and recommendations for further research.

\section{Literature review}

\section{The South African third-party logistics service providers industry}

South Africa is the most developed country in Africa engaging in 3PL services (Karrapan et al. 2017:3). The logistics industry in South Africa is a significant contributor to the economy and supports the country in achieving a global competitive advantage (Havenga, De Bod \& Simpson 2016:6). The South African 3PL industry is also highly competitive, as an increasing number of firms are outsourcing their logistical functions (Waugh \& Luke 2011:377). A 3PL performs various logistical activities for shippers or distributors and customers (Grant et al. 2014:214). These logistical activities include: warehousing, inbound and outbound transportation and value-added services, such as repackaging and logistics network design (Coyle et al. 2013:118). The 3PLs operate in various industry verticals, which include the FMCG industry, the automotive industry, the manufacturing industry, and the retail industry (Foulds 2013:32). The role of 3PLs in developing countries such as South Africa is changing, as they can now be viewed as value-adding orchestrators within supply chains (Niemann et al. 2018:1743). The 3PLs are more focused on new ways of interaction with their clients and the type of valueadded services offered (Niemann et al. 2018:1743). Furthermore, developing countries are more at risk to experience SCDs than developed countries (Tukamuhabwa, Stevenson \& Busby 2017:487). The South African logistics industry is particularly vulnerable to SCDs, as found in a recent study by Nel et al. (2018:1-12). These SCDs include, but are not limited to, labour unrest, border delays, cargo theft and political instability.

\section{Supply chain disruptions}

Firms are vulnerable to various risks, ranging from operational risks and financial risks to reputational risks (Porterfield, Macdonald \& Griffis 2012:400-401; Verbano \& Venturini 2013:189). A SCD can be described as an unanticipated or unforeseen event that results in an interruption in the ordinary flow of goods and materials within a supply chain network (Craighead, Blackhurst, Rungtusanatham \& Handfield 2007:132; Porterfield et al. 2012:402). The effects of SCDs propagate throughout the entire supply chain network and can have detrimental effects on each network member (Heckmann, Comes \& Nickel 2015:121). Supply chain disruptions are inevitable. It is no longer a matter of whether SCDs will occur, but rather when they will occur (Glendon \& Bird 2013:4). In order to limit the effect of SCDs on firm performance and corporate reputation, firms have to identify, respond and retaliate to SCDs in a timely and effective manner (Chang, Ellinger \& Blackhurst 2015:643; Markova et al. 2018:26). This illustrates the importance of implementing appropriate supply chain disruption management (SCDM) processes (Behdani et al. 2012:7-8; Revilla \& Saenz 2017:7).

\section{Supply chain disruption management}

Both proactive and reactive approaches exist to analyse SCDs. These approaches can respectively be referred to as supply chain risk management and SCDM (Dani \& Deep 2010:396). Traditional risk management practices involve the process of detecting potential sources of risks and the implementation of appropriate strategies to reduce the probability of an SCD from occurring (Behdani 2013; Jüttner, Peck \& Christopher 2003:200). The disruption management cycle is only implemented once traditional risk management practices fail to prevent the SCD from occurring (Behdani 2013). Despite the vast amount of planning and research in the field of risk management, SCDs still occur (Behdani et al. 2012). The SCDM can be defined as a systematic and ongoing process of managing and analysing the impact of SCDs throughout their entire disruption lifecycle (Behdani et al. 2012:8). The disruption management cycle comprises four actions, namely disruption detection, disruption reaction, disruption recovery and disruption learning (Ahmad, Hafeez, Rodriguez \& Dawood 2016:80-93; Behdani 2013).

The first step in the disruption management cycle is to ensure that a disruption can be detected as fast as possible (DuHadway et al. 2019:190). In this step, the characteristics and expected repercussions of the SCD are outlined (Sheffi 2015:36). After the SCD has occurred, it is of vital importance to react in a timely and efficient manner. The goal of the disruption reaction step is to return the operations of the affected firm back to a normal state of functioning (Ivanov \& Dolgui 2020:2907). This step can be conducted through implementing a pre-determined plan, which can result in timesaving during the reaction period and could potentially limit the impact of the SCD on the firm's performance (Scholten, Sharkey Scott \& Fynes 2014:222). If this step fails to bring the operations back to a normal state of functioning, the following steps should be deployed.

In the disruption recovery step, the SCD is continuously monitored whilst information pertaining to the SCD is collected (Holzhauer 2016:34). Collaboration during this stage is crucial, as it is too late to implement preventative measures and it is known that parties can recover more successfully when working together (Scholten et al. 2014:219). The SCDR is not only the third step of the SCDM process, but it also forms an integral part of the supply chain resilience (SCRES) (Adobor \& McMullen 2018:1452; Hohenstein, Feisel \& Hartmann 2015:99). The basic premise of SCRES is to restore a firm's operations back to a normal state of functioning after an SCD has occurred (Ambulkar, Blackhurst \& Grawe 2015:112). The SCRES also builds the ability and capability to recover from SCDs and to adapt to new risk environments (Bukowski \& Feliks 2012:3). The main elements of SCRES include: readiness, response, recovery and growth (Hohenstein et al. 2015:99-101). Recovery is viewed as a central element to SCRES by many researchers (Blackhurst, Kaitlin \& Craighead 2011:383; $\mathrm{Wu}$ et al. 2013:678). The recovery element focuses on the spontaneous response to SCDs, as pre-determined plans failed to suffice (Holzahuer 2016:34). A part of the SCDR process is to 
restore damaged reputations between supply chain network partners, as a damaged reputation is a direct consequence of an SCD (Paul, Sarker \& Essam 2018:2; Porterfield et al. 2012:417).

The final step in the SCDM cycle refers to the evaluation of the implemented measures during the lifetime of the SCD (Behdani 2013). In this step, the lessons learnt will be documented in order to prepare for future SCDs.

\section{Corporate reputation}

A corporate reputation is the derived impression of who and what a firm represents. This impression can be acquired through either observing the way that a firm manages its assets or through individual experiences (Lloyd 2011:109; Reese \& Kossovsky 2011:24). Individuals can use various approaches to develop their impressions of a firm. These include personal experiences, the media, interaction with the firm's employees and their history of conducting business with a firm (Lemke \& Petersen 2013:414). A corporate reputation can further be referred to as a collection or accumulation of these individual perceptions and can be both positive and negative (Kim, Youn \& Lee 2019:683).

A corporate reputation has a high probability of being shifted from one network member to another (Horn et al. 2015:193). The supply chain network consists of both 'reputational owners' and 'reputational borrowers'. The reputational owners can be viewed as the firms that readily develop their corporate reputation by means of their market offering, communication with its customers and their participation in the community in which they operate. The reputation borrowers are the other firms in the supply chain network, such as the upstream suppliers and downstream customers, which gain corporate reputation from the reputation owners by means of association (Hoejmose, Roehrich \& Grosvold 2014:80; Petersen \& Lemke 2015:418). The transference of corporate reputation from one network member to another illustrates the ripple effect that corporate reputation has (Morgan 2018:1). A good corporate reputation can serve as a foundation to competitive advantage (Flatt \& Kowalczyk 2011:4), it can reduce the negative impact of an SCD on a firm (Vanhamme \& Grobben 2009:275) and ultimately it can increase the interest of potential clients (Soppe et al. 2011:310). Consequently, a good corporate reputation is regarded as a valuable and scarce resource and should be managed accordingly (Iwu-Egwuonwu 2011:198; Szwajca 2018:165).

\section{Reputational risk management}

Reputational risk can be defined as the risk of failure to fulfil customer expectations with regard to performance and behaviour (Fitzsimmons \& Atkins 2017:39; Roehrich et al. 2014:698). The expectations of customers can be compromised through events that stem from both external and internal events. External events refer to the location of the supplier, the industry environment in which the firm operates and uncontrollable events, such as natural disasters. Internal events refer to firm-specific issues and managerial decision making (Hoejmose et al. 2014:80). There are various sources of reputational risks that can occur as a result of firm activities or the actions of their network partners (Roehrich et al. 2014:698). Gaudenzi et al. (2015:248-260) categorised the sources of reputational risk as macro-environmental risk drivers, operations risk drivers, finance risk drivers and supply chain risk drivers. Consequently, it is known that no firm is immune to reputational risk originating from negligible practices in their supply chain network. This calls for the effective management of reputational risk.

\section{Reputational risk management framework}

Various approaches exist to manage risks, which include risk avoidance, risk transference, risk mitigation and risk acceptance (Markova et al. 2018:26). However, because of the complex nature of reputational risk, it cannot be managed by applying traditional risk management practices. Estimating the likelihood of occurrence of reputational risk and the cost to the firm requires great effort and is known to be complicated (Lemke \& Petersen 2013:416). Despite it being possible to quantify the physical damage of an SCD, it is not possible to assess its impact on the consumer's perception of a firm's performance. The following framework (see Figure 1) suggested by Gatzert and Schmidt (2015:26-45), presents a methodical framework, which includes the necessary steps and processes for managing reputational risk. There are four broad areas to be discussed, each with comprehensive steps. These four areas are risk strategy, risk assessment, risk governance and risk culture, which are illustrated in Figure 1 (Gatzert \& Schmidt 2015:31).

In the first step of this framework, the activities to be conducted must be aligned and coordinated with the firm's overall strategic objectives. Thereafter, a risk appetite will be developed, which will define the reputation risk and how it will be measured. Based on the firm's distinct characteristics, experiences and objectives, the firm will choose to either accept, transfer, mitigate or avoid certain reputational risks (Gatzert \& Schmidt 2015:31; Grace et al. 2015:295).

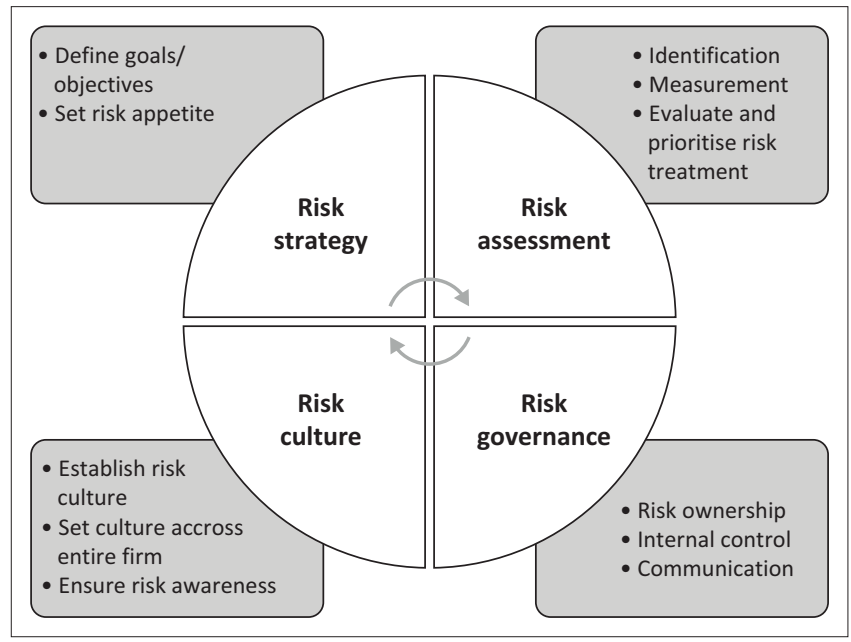

Source: Adapted from Gatzert, N. \& Schmidt, J., 2015, 'Supporting strategic success through enterprise-wide reputation risk management', The Journal of Risk Finance 17(1), 26-45. https://doi.org/10.1108/JRF-09-2015-0083

FIGURE 1: Reputational risk management framework. 
The second step of this framework includes the performing of the following activities. First, the reputational risk will be identified by assigned knowledgeable teams. This is performed through brainstorming sessions and interviews with internal and external experts. The potential risks identified should include both intra-organisational risks and risks that can stem from external network partners, such as upstream suppliers and downstream customers. Second, an evaluation of the potential risk sources should be conducted. In order to successfully measure the potential reputational risk sources both qualitative and quantitative measures will be used. Thereafter, the appropriate risk response should be implemented. Possible risk responses include risk avoidance, risk mitigation, risk transfer or risk acceptance. Risk avoidance will mean that the firm will refrain from conducting certain activities in order to avoid the potential reputational risk from occurring in its entirety. Risk mitigation entails conducting certain activities that can reduce the likelihood and/or negative impact of an SCD. Risk transfer is the shifting of reputational risk to an external party through buying reputational insurance policies (Cummins, Lewis \& Wei 2006:2610; Gatzert 2015:486). In the case of risk acceptance, a firm will continue to operate without implementing preventive measures and is willing to bear all costs implicated by the risk. This will only be done if the risk has little relevance to the firm and it has a low probability of occurring. The final activity within this step is to monitor the risk by actively updating the risk identification information to ensure that the correct measures are taken to accommodate for the changing environment (Gatzert \& Schmidt 2015:31-32; Kunitsyna, Britchenko \& Kunitsyn 2018:946).

Risk governance entails the identification of key stakeholders, the establishment of risk ownership and the development of strong internal and external communication channels. In this step, the 'risk owner' is identified within a firm. The risk owner will be one person in a firm who is responsible for the overall management of reputation risks, including the building and defending of a corporate reputation, as well as to define strategies that will limit the damages to the reputation. Another activity to be conducted within this step is to establish a communication and response strategy to potential reputational risks. This will include the development of an internal reporting system and the appointment of a spokesperson who will be responsible for all communication with external parties regarding the reputation of the firm (Binkhorst \& Kingma 2012:917; Gatzert \& Schmidt 2015:32).

The final step in this framework refers to the establishment of a strong risk culture that will ensure the general risk awareness of the firm and increased accountability for internal actions. Senior management is responsible for setting an example to lower level employees by demonstrating the required risk approaches. Employees are also trained to increase their awareness of newly evolving reputational risks (Gabbi, Pianorsi \& Soana 2017:179; Gatzert \& Schmidt 2015:34). This will ensure increased accountability when making decisions (Brooks 2010:87).

\section{Tools for effective reputational risk management}

Various tools for the effective management of reputational risk management exist, to facilitate the creation of brand awareness, increasing the image of the firm and to analyse customer feedback (Altunbas \& Diker 2015:43). Social media can be viewed as one of the most effective tools for the management of reputational risk, as it can be used to gain customer loyalty, increase customer satisfaction and identify potential risks (Altunbas \& Diker 2015:45). It is important to note that social media can further impose risks to a firm's corporate reputation and should therefore be managed cautiously (Becker \& Wan Lee 2019:233). More traditional tools to manage reputational risk include surveys, focus groups and polls. These tools are specifically used to gain feedback in order to measure the success of a firm's corporate reputation and its relationships with its network members (McCorkindale \& DiStaso 2015:503504). Reputational risk can also be managed through conventional contractual obligations concerning agreed upon service levels, regarding availability, quality and cost (Petersen \& Lemke 2015:508). Partnering programmes can also be used to manage reputational risk. These programmes entail network members working together in order to minimise the risk and are known to be effective (Jakob 2012:259). However, they have a limited influence on network members further down the supply network (Petersen \& Lemke 2015:508).

\section{Methodology Research design}

This study used a generic qualitative research design to explore a phenomenon in its natural environment and to gain a deeper understanding thereof (Creswell \& Poth 2017:7). In this case, the researchers explored reputational risk management during the SCDR process. The study employed primary data that were collected through semi-structured interviews with various participants.

\section{Sampling}

The units of analysis for this study were the triadic relationships between 3PLs, their upstream suppliers and downstream customers, operating in South Africa. Fifteen individuals from different firms participated in this study, of which five were upstream suppliers, five were 3PLs and five were downstream customers. This allowed for the successful interviewing of five logistics triads. Through implementing purposive sampling, the researchers were able to select and recruit applicable logistics triads and the most suitable individuals who could make a valuable contribution to the phenomenon under investigation (Creswell 2012:206; Gentles et al. 2015:1778).

Snowball and homogenous sampling were used as the specific purposive sampling methods. Snowball sampling requires researchers to request referrals from participants who form part of the inclusion criteria. Therefore, snowball 
sampling was the most appropriate method, as the study required the perspective of triadic relationships between 3PLs, upstream suppliers and downstream customers. Another sampling method used was homogenous sampling, which is used to recruit participants who possess similar characteristics (Creswell 2012:208). Homogenous sampling is particularly useful when a deeper comprehension about the phenomenon under investigation is required, as it decreases the variability in the sample (Isaacs 2014:320; Polit \& Beck 2012:518). In this study, the 3PL firms were sampled first and then the respective upstream suppliers and downstream customers, all of which met the set inclusion criteria.

The first level of sampling included the recruitment of the 3PL firms and the firms of their respective upstream suppliers and downstream customers and was conducted as follows: First, as the study required a triadic perspective, firms who did not form part of a direct relationship with the 3PL were excluded from the study. Second, the relationship between the firms had to be established for a minimum duration of 1 to 2 years, as an established relationship would be of strategic nature and not merely transactional. In addition, all participating firms had to operate in South Africa. Finally, the participating firms had to experience a mutual SCD, that is, within their supply chain network, as SCDR forms part of the context of the study.

The second level of sampling included the recruitment of the individual participants. The individual participants were selected based on the following inclusion criteria. First, the individuals had to be in either mid- or seniorlevel management, as this ensured that the participant had experience in his or her field. Second, the individual had to be working at the firm in question for at least 12 months and should have had frequent interaction with the rest of the firms in the logistics triad. This ensured that the direct link between the firms could be investigated. Finally, the participant must have experienced an SCD with the other firms in the logistics triad, as this enabled the participants to provide valuable insights concerning the SCDR process. Table 1 outlines the details of the participants interviewed.

\section{Data collection}

Fifteen semi-structured interviews were conducted to gain a deeper understanding of the phenomenon under investigation (Creswell 2012:218; Patton 2015:14). The interviews were guided by a discussion guide; however, the interviews were not limited to these questions and questions were added spontaneously in order to gather more information (Cachia \& Millward 2011:268). The discussion guide was pre-tested with a participant who met the inclusion criteria. Interviews were conducted online using a webcam-enabled device. The interviews were conducted within a 45-min time frame and the average interview was $36 \mathrm{~min}$ long. Permission to audio $\approx$ record the conversation was obtained before the
TABLE 1: Details of participants interviewed.

\begin{tabular}{|c|c|c|c|}
\hline Pseudonym & Position & Gender & $\begin{array}{l}\text { Length of } \\
\text { interview }\end{array}$ \\
\hline U1 & Head: Courier division & Male & 44:13:00 \\
\hline $\mathrm{T} 1$ & $\begin{array}{l}\text { Executive: Supply chain and business } \\
\text { development }\end{array}$ & Male & $35: 25: 00$ \\
\hline D1 & $\begin{array}{l}\text { Inbound and outbound } \\
\text { transport manager }\end{array}$ & Male & $36: 13: 00$ \\
\hline U2 & Supply chain manager & Female & $28: 46: 00$ \\
\hline T2 & $\begin{array}{l}\text { Senior account director } \\
\text { (consumer, retail and fashion) }\end{array}$ & Male & 39:06:00 \\
\hline D2 & Chief executive: Supply chain & Male & $55: 16: 00$ \\
\hline U3 & Group planning manager & Male & 28:34:00 \\
\hline T3 & Key account manager & Female & 31:33:00 \\
\hline D3 & Supply chain executive & Male & 45:01:00 \\
\hline U4 & $\begin{array}{l}\text { Head of supply chain } \\
\text { (Africa and Brazil) }\end{array}$ & Male & $37: 54: 00$ \\
\hline T4 & Key account manager & Female & $26: 31: 00$ \\
\hline D4 & $\begin{array}{l}\text { International \& } 4 \mathrm{PL} \text { supply chain } \\
\text { manager }\end{array}$ & Female & 26:31:00 \\
\hline U5 & Deputy responsible pharmacist & Male & 44:50:00 \\
\hline T5 & Deputy DC manager & Male & 40:39:00 \\
\hline D5 & Senior pharmacist & Female & 20:35:00 \\
\hline
\end{tabular}

Average length of interview 36:04:00.

commencement of the interview. The informed consent form was also discussed and requested to be signed before the commencement of the interview.

\section{Data analysis}

Thematic data analysis was used to analyse the data collected in this study. Transcriptions were extensively analysed and thereafter codes were identified. Certain extracts that related to the study's research questions were assigned tags, which made up the codes of the transcriptions. Thereafter, repetitive and overlapping codes were grouped together to prevent redundancy. Finally, sense-making of the data took place, where sub-themes and themes were identified (Braun \& Clarke 2012:57).

\section{Trustworthiness}

The study applied Lincoln and Guba's (1985) trustworthiness criteria, in order to demonstrate the credibility, dependability, confirmability and transferability of the study (Polit \& Beck 2012:584). Credibility requires the alignment of the participants' perspectives and the true state of the phenomenon under investigation (Polit \& Beck 2012:585; Shenton 2004:64). Before the interviews commenced, the participants' anonymity and confidentiality were communicated to ensure that the participants provided their full and honest account of events throughout the interviews. Dependability or auditability refers to the potential of a study's findings to be consistently replicated when applied to a comparable context with comparable participants (Polit \& Beck 2012:585) and to comply with the dependability criteria (Lincoln \& Guba 1985:43). The study includes an audit trail, which outlines the methodology applied (Lietz \& Zayas 2010:196). Confirmability indicates whether the findings of the study are a true reflection of the participants' accounts and are presented in an objective manner that is not influenced by the researcher's own preferences or biases 
(Polit \& Beck 2012:585). The study developed broad openended interview questions so that participants could provide an unbiased account of events. The researchers also transcribed the interviews in great detail to ensure the accuracy of the data collected (Milne \& Oberle 2005:415). Transferability is the ability of a study's findings to be applied to a similar context or situation (Polit \& Beck 2012:585; Liamputtong 2013:26). The researchers provided sufficient detail on the study's context for future researchers. This will allow the future researchers to determine whether the study can be applied to a new context or not (Shenton 2004:70).

\section{Ethical considerations}

Before the commencement of the interviews, each participant read and signed the informed consent form where they voluntarily agreed to participate in this study. The anonymity and confidentiality of the participant's names and responses were also discussed before the commencement of the interviews. Furthermore, the confidentiality and anonymity of the participants were ensured by assigning and using pseudonyms throughout the study.

\section{Findings}

This study has identified two main themes with four subthemes that relate back to the study's research questions. The main themes include: approaches used to manage reputational risk during SCDR, and the influence of reputational risk on the SCDR process. These themes are followed by their respective sub-themes and are supported by raw data extracts. Table 2 illustrates the linkage between the themes, sub-themes and codes.

\section{Theme 1: Approaches used to manage reputational risk during supply chain disruption recovery}

The first theme corresponds with research question one, as it refers to the specific approaches that logistics triads follow to

TABLE 2: Summary of themes, sub-themes and codes.

\begin{tabular}{|c|c|c|}
\hline $\begin{array}{l}\text { Research } \\
\text { questions }\end{array}$ & $\begin{array}{l}\text { RQ1: How do logistics } \\
\text { triads manage reputational } \\
\text { risk during supply chain } \\
\text { disruption recovery? }\end{array}$ & $\begin{array}{l}\text { RQ2: How does reputational risk } \\
\text { influence the supply chain disruption } \\
\text { recovery process between members } \\
\text { of a logistics triad? }\end{array}$ \\
\hline Themes & $\begin{array}{l}\text { Approaches used to manage } \\
\text { reputational risk during } \\
\text { supply chain disruption } \\
\text { recovery. }\end{array}$ & $\begin{array}{l}\text { The influence of reputational risk on } \\
\text { the supply chain disruption recovery } \\
\text { process. }\end{array}$ \\
\hline Sub-themes & $\begin{array}{l}\text { Formal approaches: } \\
\text { - Control centres } \\
\text { - Customer service teams } \\
\text { - Global corporate policies } \\
\text { - Key account manager } \\
\text { involvement } \\
\text { - Use of performance } \\
\text { measurement systems } \\
\text { - Standard operating } \\
\text { procedures } \\
\text { Informal approaches: } \\
\text { - Customer engagement } \\
\text { during recovery } \\
\text { - Internal collaboration } \\
\text { - Network partner } \\
\text { collaboration } \\
\text { - Feedback sessions post } \\
\text { recovery } \\
\text { - Communication tools }\end{array}$ & $\begin{array}{l}\text { Enabling-facilitating impact } \\
\text { - Enables quicker recovery } \\
\text { - Helps gain confidence in service } \\
\text { capability } \\
\text { Damaging-hindering impact } \\
\text { - Lost confidence in service ability } \\
\text { - Unsuccessful recovery because of } \\
\text { lost customers }\end{array}$ \\
\hline
\end{tabular}

manage reputational risk during SCDR. The study identified 13 reputational risk management approaches used during SCDR. Subsequently, the approaches were categorised according to their uses, namely formal and informal approaches. Table 3 provides an outline of theme one with extracts from the data to support the findings.

\section{Formal approaches}

Formal approaches refer to established approaches that form part of the contractual obligations set between the members of the logistics triad. These approaches are developed before the initiation of the relationships and are set in place to guide network members through SCDs. The formal approaches identified include: control centres, customer service teams, global corporate policies, key account manager involvement, the use of performance measurement systems and standard operating procedures.

Control centres are centralised pre-established teams that take the lead in managing reputational risk once a disruption has occurred. These teams serve as the hub of managing reputational risk, as they govern all decisions to be made during SCDR. This assists firms in managing the reputational risk during SCDR. One participant mentioned control centres as an approach to managing reputational risk during SCDR.

Customer service teams are dedicated teams that deal with customer queries during SCDR and help to manage the customer-induced uncertainty. Customer service teams consist of trained professionals who deal with the customers of firms. These teams help to manage the reputational risk from the customer's perspective during SCDR. Two participants highlighted the implementation of customer service teams as an approach in managing reputational risk during SCDR.

Another approach used to manage reputational risk during SCDR is the use of global corporate policies and standard operating procedures. Two participants described these as blueprints that are set by a firm's head offices that guide firms through reputational risk management during SCDR. These policies and procedures are agreed upon by all network members and help to govern the actions of the members during SCDR. This helps to manage reputational risk, as all network members have a clear understanding of their role in the SCDR process.

Key account manager's involvement can also be used as an approach to manage reputational risk during SCDR. Key account managers are assigned employees who consistently engage with a firm's suppliers during SCDR, and this assists in managing the reputational risk. The key account managers are dedicated to these specific suppliers and serve as the link in communication between the two network members. Two participants described the use of key account manager involvement as an approach to manage reputational risk during SCDR. 
TABLE 3: Reputational risk management approaches used during supply chain disruption recovery.

\begin{tabular}{|c|c|c|c|c|c|c|c|c|c|c|c|c|c|c|c|c|c|c|c|}
\hline \multirow{2}{*}{$\begin{array}{l}\text { Approaches used to manage } \\
\text { reputational risk during SCDR }\end{array}$} & \multicolumn{5}{|c|}{ Upstream suppliers } & \multirow[t]{2}{*}{ Total } & \multicolumn{5}{|c|}{ 3PLs } & \multirow[t]{2}{*}{ Total } & \multicolumn{5}{|c|}{ Downstream customers } & \multirow[t]{2}{*}{ Total } & \multirow[t]{2}{*}{ Supporting data extracts } \\
\hline & U1 & U2 & U3 & U4 & U5 & & T1 & T2 & T3 & T4 & T5 & & D1 & D2 & D3 & D4 & D5 & & \\
\hline \multicolumn{20}{|l|}{ Formal approaches } \\
\hline Control centres & & & & & & 0 & & & & & & 0 & & & & $\checkmark$ & & 1 & $\begin{array}{l}\text { '...the control centre lets you } \\
\text { intervene from supplier all the } \\
\text { way through to store...' (D4, } \\
\text { female, International \& 4PL } \\
\text { supply chain manager) }\end{array}$ \\
\hline Customer service teams & & & & $\checkmark$ & & 1 & & & & & & 0 & $\checkmark$ & & & & & 1 & $\begin{array}{l}\text { 'we have a dedicated customer } \\
\text { service team, group, that deals } \\
\text { with these customer service } \\
\text { interactions. They are trained to } \\
\text { deal with our customers...' (U4, } \\
\text { male, Head of supply chain) }\end{array}$ \\
\hline Global corporate policies & & & & & & 0 & & & & $\checkmark$ & & 1 & & & & & & 0 & $\begin{array}{l}\text { 'We, we have, uh, global } \\
\text { corporate policies in place } \\
\text { around stuff like that...' (T4, } \\
\text { female, Key account manager) }\end{array}$ \\
\hline $\begin{array}{l}\text { Key account manager } \\
\text { involvement }\end{array}$ & & & & & & 0 & & & $\checkmark$ & $\checkmark$ & & 2 & & & & & & 0 & $\begin{array}{l}\text { 'I mean, we're not going to } \\
\text { allow reputation to just go } \\
\text { down the drain, not at all. And, } \\
\text { you know, we have, we have } \\
\text { individuals who, you know, can } \\
\text { also assist us with that kind of } \\
\text { thing, such as our key accounts } \\
\text { managers'. (T4, female, Key } \\
\text { account manager) }\end{array}$ \\
\hline $\begin{array}{l}\text { Use of performance } \\
\text { measurement systems }\end{array}$ & $\checkmark$ & & & & & 1 & & $\checkmark$ & & $\checkmark$ & $\checkmark$ & 3 & & & & & & 0 & $\begin{array}{l}\text { 'So, you need transparent KPIs } \\
\text { where you can identify where } \\
\text { things are going wrong...' (T2, } \\
\text { male, Senior account director) }\end{array}$ \\
\hline Standard operating procedure & $\checkmark$ & & & & & 1 & & & & & & 0 & & & & & & 0 & $\begin{array}{l}\text { 'Um, we obviously had our SOPs } \\
\text { that governed us...' (U1, male, } \\
\text { Head: Courier division) }\end{array}$ \\
\hline Total perspective & & & & & & 2 & & & & & & 4 & & & & & & 2 & Total \\
\hline \multicolumn{20}{|l|}{ Informal approaches } \\
\hline $\begin{array}{l}\text { Customer engagement during } \\
\text { recovery }\end{array}$ & & & $\checkmark$ & & & 1 & & & & & & 0 & & & & & & 0 & $\begin{array}{l}\text { '...I mean, we, we basically, sat } \\
\text { together to speak to our } \\
\text { customer and through that } \\
\text { managed our image'. (U3, male, } \\
\text { Group planning manager) }\end{array}$ \\
\hline Network partner collaboration & & & & & & 0 & & $\checkmark$ & & & & 1 & & & $\checkmark$ & $\checkmark$ & & 2 & $\begin{array}{l}\text { 'We would try and work with } \\
\text { which ever one of our network } \\
\text { partners dropped the ball and } \\
\text { get them involved in the } \\
\text { process of mitigating the } \\
\text { reputational damage...' (T2, } \\
\text { male, Senior account director) }\end{array}$ \\
\hline Feedback sessions post-recovery & $\checkmark$ & & & & & 1 & & & & & & 0 & & $\checkmark$ & $\checkmark$ & & & 2 & $\begin{array}{l}\text { '...I think it's important to touch } \\
\text { base with your client base } \\
\text { afterwards'. (U1, male, Head: } \\
\text { Courier division) }\end{array}$ \\
\hline Communication tools & & $\checkmark$ & & $\checkmark$ & $\checkmark$ & 3 & $\checkmark$ & & & & & 1 & & & & & & 0 & $\begin{array}{l}\text { 'Um, so clear communication, } \\
\text { emails that's sent out explaining } \\
\text { to them the situation and, um, } \\
\text { and what processes and steps } \\
\text { she's taken and what their } \\
\text { expectations can be of us, um, } \\
\text { needs to be in place'. (T5, male, } \\
\text { Deputy DC Manager) }\end{array}$ \\
\hline Total per member & & & & & & 5 & & & & & & 3 & & & & & & 3 & Total \\
\hline
\end{tabular}

SCDR, supply chain disruption recovery.

The final approach to managing reputational risk during SCDR is the use of performance measurement systems, such as service level agreements and formal key performance indicators. Four participants mentioned these measurements as approaches that can help firms to identify areas where reputational risk occurs. They also aid firms in monitoring these high-risk areas and subsequently manage SCDR.

Evidently 3PLs view the use of formal approaches as imperative in managing reputational risk during SCDR, whereas upstream suppliers and downstream customers only use formal approaches to a limited extent. As 3PLs are service providers to both upstream suppliers and downstream customers, it is important that they use formal approaches to manage reputational risk during SCDR. This will aid them in providing a consistent service to all their customers. This is confirmed by the raw data extracts found in Table 4 .

\section{Informal approaches}

Informal approaches refer to reputational risk management approaches that are developed spontaneously during the attempt to recover from a SCD. These approaches are not 
TABLE 4: Influences of reputational risk on the supply chain disruption recovery process.

\begin{tabular}{|c|c|c|c|c|c|c|c|c|c|c|c|c|c|c|c|c|c|c|c|}
\hline \multirow{2}{*}{$\begin{array}{l}\text { The influence of reputational } \\
\text { risk on the supply chain } \\
\text { disruption recovery process }\end{array}$} & \multicolumn{5}{|c|}{ Upstream suppliers } & \multirow[t]{2}{*}{ Total } & \multicolumn{5}{|c|}{ 3PLS } & \multirow[t]{2}{*}{ Total } & \multicolumn{5}{|c|}{ Downstream customers } & \multirow[t]{2}{*}{ Total } & \multirow[t]{2}{*}{ Supporting data extracts } \\
\hline & U1 & U2 & U3 & U4 & U5 & & $\mathrm{T} 1$ & $\mathrm{~T} 2$ & T3 & T4 & T5 & & D1 & D2 & D3 & D4 & D5 & & \\
\hline \multicolumn{20}{|l|}{ Enabling-facilitating impact } \\
\hline Enables higher service level & & & & & & 0 & $\checkmark$ & & & & & 1 & & & $\checkmark$ & & & 1 & $\begin{array}{l}\text { 'The spindle was that we } \\
\text { actually won additional } \\
\text { contracts that were in a test } \\
\text { phase of our supply chain, it } \\
\text { sort of gave it credence and } \\
\text { gave it a proper validation and } \\
\text { customers onboarded } \\
\text { themselves quicker than they } \\
\text { would have done naturally as a } \\
\text { proof in the pudding kind of } \\
\text { concept by executing our } \\
\text { services'. (T1, male, Executive: } \\
\text { Supply Chain \& Business } \\
\text { development) }\end{array}$ \\
\hline Total per perspective & & & & & & 2 & & & & & & 2 & & & & & & 1 & Total \\
\hline \multicolumn{20}{|l|}{ Damaging-hindering impact } \\
\hline Lost confidence in service ability & & & & & & 0 & & & $\checkmark$ & & & 1 & & & & & & 0 & $\begin{array}{l}\text { '...there's a bit of reluctance for } \\
\text { some of the projects because } \\
\text { they they're quite scared that } \\
\text { what they face this year is going } \\
\text { to roll on to next year. So none } \\
\text { of the plans for next year and } \\
\text { the projects that we want to do } \\
\text { for next year will be successful if } \\
\text { we're in the same situation as } \\
\text { what we are currently in'. (T3, } \\
\text { female, Key account manager) }\end{array}$ \\
\hline $\begin{array}{l}\text { Unsuccessful recovery due to lost } \\
\text { customers }\end{array}$ & & & & & & 0 & & & & & $\checkmark$ & 1 & $\checkmark$ & & & & & 1 & $\begin{array}{l}\text { 'Um, if we cannot deliver the, } \\
\text { um, our services to the best, it's } \\
\text { easy for our customers, uh, to } \\
\text { open accounts with another } \\
\text { wholesaler'. (T5, male, Deputy } \\
\text { DC manager) }\end{array}$ \\
\hline Total per member & & & & & & 0 & & & & & & 2 & & & & & & 1 & Total \\
\hline
\end{tabular}

regulated by set rules or contractual obligations. Therefore, these specific approaches can be categorised as unplanned, informal approaches. The informal approaches identified include: customer engagement during recovery, internal collaboration, network partner collaboration, feedback sessions post recovery and communication tools.

Customer engagement during recovery refers to the linkage that is formed between customers and suppliers during SCDR to help manage reputational risk. One participant explained how regular interaction with customers during SCDR can help to manage reputational risk. The customer is constantly kept updated on the recovery process, which helps to manage the firm's reputation.

Internal collaboration takes place when firms' internal functions work together to manage reputational risk that occurs with their network partners during SCDR. One participant explained how the functions of a firm can convey a consistent message to network partners, which aids in managing the reputational risk during SCDR.

Network partner collaboration helps to manage reputational risk during SCDR as the firm and its network partners work together to recover from a disruption. This external collaboration helps network partners to identify responsible parties that have to take the lead in managing the SCDR processes and in turn protects the corporate reputation of the other network partners involved. Three participants mentioned the use of network partner collaboration as an effective approach to managing reputational risk during SCDR.

Feedback sessions post recovery were highlighted as an important approach to manage reputational risk during SCDR by three participants. These feedback sessions refer to regular meetings or sessions held with network partners after the SCDR process has taken place. This helps to establish a trusting relationship, which aids in managing reputational risk during SCDR.

Finally, communication tools such as emails and social media are used to communicate with network partners, which assist in managing the reputational risk of firms during SCDR. These communication tools are put in place to convey important messages to the firm's network partners. These messages usually contain real-time information, which helps network partners to understand the SCDR process better and in turn helps to manage the reputational risk. Four participants mentioned the use of communication tools to manage reputational risk during SCDR.

Evidently upstream suppliers prefer to use informal approaches to manage reputational risk during SCDR, whereas 3PLs and downstream customers use informal tools only to a limited 
extent. This may be as a result of the position of the upstream supplier in the supply chain network. Upstream suppliers have more difficulty in managing SCDs downstream, and therefore they cannot plan and develop formal approaches. Hence, upstream suppliers prefer to use unplanned, spontaneous informal approaches to manage reputational risk during SCDR. This is confirmed by the raw data extracts found in Table 3 .

The findings confirm various approaches to manage reputational risk found in literature. First, the study confirms the use of social media as an effective reputational risk management approach used during SCDR (Altunbas \& Diker 2015:45). Second, the use of more traditional approaches, such as customer engagement and communication, is also confirmed (McCorkindale \& DiStaso 2015:503-504). Third, the findings correlate with the use of contractual obligations as an approach to manage reputational risk during SCDR, as the study found formal approaches, such as set standard operating procedures and service level agreements to be evident (Bernstein 2015:563; Petersen \& Lemke 2015:508). Finally, partnering programmes or collaborative efforts as observed by Jakob (2012:259), were also found to be evident in this study's findings. Furthermore, the study identified additional approaches to managing reputational risk during SCDR that are not evident in literature. These approaches are all categorised as formal and include the use of control centres, global corporate policies and key account manager involvement.

\section{Theme 2: The influence of reputational risk on the supply chain disruption recovery process}

The second theme relates back to research question two as it addresses the influence that reputational risk has on the SCDR process. The study identified four different impacts that reputational risk has on the SCDR process. Thereafter, the impacts were divided according to whether they enabled the process or hindered the process. Table 4 provides a summary of theme two and includes data extracts that support the findings.

\section{Enabling-facilitating impact}

The Enabling-facilitating impact refers to how reputational risk can, in effect, allow the SCDR process to be conducted more effectively and efficiently. The enabling or facilitating impact stems from two sources, namely quicker recovery and the motivation to perform at a higher service level. The study found that reputational risk served as a motivator for firms to retain their customers and resulted in a more successful recovery. Four participants mentioned that reputational risk helped them to recover quicker from the SCD, as they were focused on maintaining a strong corporate reputation and therefore had to act quicker in the recovery process. This is illustrated by the data extract found in Table 4. One participant mentioned that reputational risk enabled a more effective recovery, as the firm was forced to perform at a higher service level in order to maintain the strong corporate reputation. This also resulted in the establishment of successful future relationships, which is a direct result of a successful SCDR process. The supporting data extract can be found in Table 4 .

\section{Damaging-hindering impact}

The Damaging-hindering impact refers to the negative consequences that reputational risk can have on the SCDR process. The study found that reputational risk can serve as a hindrance in recovering more successfully from an SCD. This is as a result of two factors, namely the network partners' loss of confidence in the firm's service ability and ultimately the loss of customers. One participant mentioned that the reputational risk hindered successful recovery as a result of their network partners losing confidence in their firm's ability to perform at certain service levels. The network partners were reluctant to engage with the firm in future projects and this resulted in the recovery process being unsuccessful. The supporting data extract can be found in Table 4. Two participants observed that they lost customers because of the reputational risk, which in turn hindered the SCDR process. As the firm was unable to deliver at certain service levels, its network partners decided to take their business elsewhere. The loss of customers because of an SCD is a prime example of a failed SCDR attempt and thus exemplifies how reputational risk can lead to an unsuccessful SCDR process. This is illustrated by the data extract found in Table 4.

The study found that more participants view the influence of reputational risk on the SCDR process as positive since reputational risk motivated the firms to recover in a more efficient and effective manner. These findings were evenly distributed across all perspectives and it can be concluded that all perspectives have the same perception of the influence that reputational risk has on the SCDR process.

Existing literature emphasises how reputational risk can be damaging to all aspects of a firm, including its ability to recover from SCDs (Galuchi et al. 2019:158; Morgan 2018:1). However, the findings of this study clearly contradict this statement as most participants stated that reputational risk has an enabling or facilitating impact on the SCDR process. Instead, reputational risk enables the SCDR process to be conducted more efficiently and effectively. Reputational risk also serves as a motivator for firms to perform at higher service levels and results in more positive outcomes, such as the winning of additional contracts and maintaining a strong corporate reputation.

\section{Conclusion}

\section{Discussion of the findings and theoretical contribution}

The aim of this study was to (1) identify the various approaches that members of a logistics triad use to manage reputational risk during SCDR, and (2) to determine the influence that reputational risk has on the SCDR process.

The first research question addressed the approaches that members of a logistics triad use to manage reputational risk 
during SCDR. The study identified 11 approaches, which were categorised as formal approaches and informal approaches. The study confirmed various approaches existent in literature. These include the use of social media (Altunbas \& Diker 2015:45), traditional approaches, such as customer engagement and communication (McCorkindale \& DiStaso 2015:503-504), contractual obligations (Bernstein 2015:563; Petersen \& Lemke 2015:508) and partnering programmes or collaborative efforts (Jakob 2012:259). Furthermore, the study identified approaches not evident in literature. These approaches relate to the use of control centres, global corporate policies and key account manager involvement.

The second research question addressed the influence that reputational risk has on the SCDR process. The study found that the reputational risk can have both an enabling and a damaging impact on the SCDR process. However, the findings of this study contradict the findings of Galuchi et al. (2019:158) and Morgan (2018:1), as it was found that reputational risk may have a positive impact on the SCDR process and is only found to be occasionally less damaging to a firm and its SCDR processes. In fact, reputational risk serves as a motivator for firms to recover quicker from an SCD and also to perform at a higher service level during SCDR.

\section{Managerial recommendations}

This study presents various managerial recommendations. First, the findings aid in creating awareness for the importance of managing reputational risk during SCDR, as it can provide various benefits if managed effectively and can potentially result in permanent damage if not managed at all. Managers can subsequently develop proactive strategies to manage the reputational risk should it occur. This will allow managers to be more prepared in managing reputational risk in future SCDs. Second, the findings provide managers with various approaches that can be used to manage reputational risk during SCDR. These approaches are applicable to all managers, irrespective of their position in the supply chain network. Managers can decide which approach is more fitting for their specific firm and potentially implement it to help manage reputational risk during SCDR.

\section{Limitations and directions for future research}

This study only obtained the opinions of the participants with regard to the approaches in managing reputational risk. The study fails to measure to what extent these approaches are practically feasible. Future investigations should consider a quantitative research methodology to consider the nature and extent of the relationships under investigation. In addition, future studies may investigate the enablers and barriers to a good corporate reputation during SCDR. Furthermore, this study was only conducted in a South African developing country context. This limited the study's findings to perspectives of a single country, which complicates the generalisability of the study's findings. Future studies can consider replicating the study in a developed country setting, to ensure consistency and transferability of the findings.

\section{Acknowledgements Competing interests}

The authors declare that they have no financial or personal relationships that may have inappropriately influenced them in writing this article.

\section{Authors' contributions}

This article is based on the MPhil dissertation of T.B. who was the main researcher. W.N. acted as the supervisor with the conceptualisation, literature review, research instrument and development of this manuscript.

\section{Funding information}

This research received no specific grant from any funding agency in the public, commercial, or not-for-profit sectors.

\section{Data availability}

Data are stored according to institutional policy.

\section{Disclaimer}

The views and opinions expressed in this article are those of the authors and do not necessarily reflect the official policy or position of any affiliated agency of the authors, and the publisher.

\section{References}

Adobor, H. \& Mcmullen, R.S., 2018, 'Supply chain resilience: A dynamic and multidimensional approach', The International Journal of Logistics Management 29(4), 1451-1471. https://doi.org/10.1108/IJLM-04-2017-0093

Ahmad, M.A., Hafeez, M.A., Rodriguez, S. \& Dawood, N., 2016, BIM: A disruptive process towards traditional practice, viewed 01 June 2020, from https://www.
researchgate.net/profile/Sergio_Rodriguez12/publication/316601594_BIM_A_d i researchgate.net/profile/Sergio_Rodriguez12/publication/316601594_BIM_A_d i s ruptive process t o wards_t ra d i t i o n a I_practice/
links/5911a3174585152e1980c5ce/BIM-A-disruptive-process-towardstraditional-practice.pdf.

Akman, G. \& Baynal, K., 2014, 'Logistics service provider selection through an integrated fuzzy multicriteria decision making approach', Journal of Industria Engineering 2014(1), 1-16. https://doi.org/10.1155/2014/794918

Alfarsi, F., Lemke, F. \& Yang, Y., 2019, 'The importance of supply chain resilience: An empirical investigation', Procedia Manufacturing 39(1), 1525-1529. https://doi. org/10.1016/j.promfg.2020.01.295

Altunbas, H. \& Diker, E., 2015, 'Corporate reputation management and social media: An analysis on Facebook accounts of the most valuable 5 brands in turkey', Akademia 4(2), 40-54. https://doi.org/10.17680/akademia.37335

Ambulkar, S., Blackhurst, J. \& Grawe, S., 2015, 'Firm's resilience to supply chain disruptions: Scale development and empirical examination', Journal of Operations Management 33(1), 111-122. https://doi.org/10.1016/j.jom.2014.11.002

Azad, A., Dhayanidhi, K. \& Narashiman, K., 2011, 'The use of third party logistics services: A literature review', International Journal of Operations System and Human Resource Management 1(1-2), 29-43.

Baghersad, M., 2018, Firms' resilience to supply chain disruptions, viewed 15 April 2020, from https://vtechworks.lib.vt.edu/handle/10919/96311.

Becker, K. \& Wan Lee, J., 2019, ,Organizational usage of social media for corporate reputation management', Journal of Asian Finance, Economics and Business 6(1), 231-240. https://doi.org/10.13106/jafeb.2019.vol6.no1.231

Behdani, B., 2013, 'Handling disruptions in supply chains: An integrated framework and an agent-based model', PhD thesis, Delft University of Technology, Delft, The Netherlands, viewed 11 April 2020, from http://repository.tudelft.nl/view/ir/ uuid:6f5e8db3-c1b7-4b2d-8035-3ae37a617564/. 
Behdani, B., Adhitya, A., Lukszo, Z. \& Srinivasan, R., 2012, How to handle disruptions in supply chains: An integrated framework and a review of literature, viewed 11 April 2020, from https://papers.ssrn.com/sol3/papers. literature, viewed 11 April

Binkhorst, J. \& Kingma, S.F., 2012, 'Safety vs. reputation: Risk controversies in emerging policy networks regarding school safety in the Netherlands', Journal of emerging policy networks regarding school safety in the Netherlands', Journal of
Risk Research 15(8), 913-935. https://doi.org/10.1080/13669877.2012.686049

Blackhurst, J., Kaitlin, S.D. \& Craighead, C.W., 2011, 'An empirically derived framework of global supply resiliency', Journal of Business Logistics 32(4), 374-391. https:// doi.org/10.1111/j.0000-0000.2011.01032.x

Braun, V. \& Clarke, V., 2012, 'Thematic analysis', in H. Cooper (ed.), APA handbook of research methods in psychology: Volume 2 Research designs, pp. 57-71, American Psychological Association, Washington, DC.

Brooks, D.W., 2010, Creating a risk-aware culture, viewed 28 April 2020, from https:// mpra.ub.uni-muenchen.de/45421/1/MPRA_paper_45421.pdf.

Bukowski, L.A. \& Feliks, J., 2012, Multi-dimensional concept of supply chain resilience viewed 12 April 2020, from http://clc2012.tanger.cz/files/proceedings/09/ reports/1218.pdf.

Business Continuity Institute, 2019, Supply chain resilience report 2019, viewed 01 March 2020, from https://www.thebci.org/uploads/assets/uploaded/c50072bfdf5c-4c98-a5e1876aafb15bd0.pdf.

Cachia, M. \& Millward, L., 2011, 'The telephone medium and semi-structured interviews: A complementary fit', Qualitative Research in Organizations and Management: An International Journal 6(3), 265-277. https://doi. org/10.1108/17465641111188420

Chang, W., Ellinger, A.E. \& Blackhurst, J., 2015, 'A contextual approach to supply chain risk mitigation', The International Journal of Logistics Management 26(3) 642-656. https://doi.org/10.1108/IJLM-02-2014-0026

Cohen, J. \& Kupferschmidt, K., 2020, 'Strategies shift as coronavirus pandemic looms', Science 367(6481), 962-963, viewed 01 March 2020, from https://science. sciencemag.org/content $/ 367 / 6481 / 962$. summary?casa token=uXUtorEMfzkAAA Aciencemag.org/content/367/6481/962. summary?casa token=uXUtorEMfzkAA AA:BFF5jH8U0750FTO-s6NExaMF
MJqSDBOfHacW0-t5MNtPyGvhQ:YtTkU.

Coyle, J.J., Langley, C.J., Novack, R.A. \& Gibson, B., 2013, Supply chain management: A logistics perspective, Cengage, Mason, $\mathrm{OH}$.

Craighead, C.W., Blackhurst, J., Rungtusanatham, M.J. \& Handfield, R.B., 2007, 'The severity of supply chain disruptions: Design characteristics and mitigation capabilities', Decision Sciences 38(1), 131-156. https://doi.org/10.1111/j.1540-5915.2007.00151.x

Creswell, J.W., 2012, Education research: Planning, conducting and evaluating quantitative and qualitative research, 4th edn., Pearson, Boston, MA.

Creswell, J.W. \& Poth, C.N., 2017, Qualitative inquiry and research design: Choosing among five approaches, 4th edn., Sage, Thousand Oaks, CA.

Cummins, J.D., Lewis, C.M. \& Wei, R., 2006, 'The market value impact of operational loss events for US banks and insurers', Journal of Banking \& Finance 30(10), 2605-2634. https://doi.org/10.1016/j.jbankfin.2005.09.015

Dani, S. \& Deep, A., 2010, 'Fragile food supply chains: Reacting to risks', International Journal of Logistics: Research and Applications 13(5), 395-410. https://doi.org/10.1080/13675567.2010.518564

DuHadway, S., Carnovale, S. \& Hazen, B., 2019, 'Understanding risk management for intentional supply chain disruptions: Risk detection, risk mitigation, and risk recovery', Annals of Operations Research 24(12), 1-20. https://doi.org/10.1007/ s10479-017-2452-0

Elluru, S., Gupta, H., Kaur, H. \& Singh, S.P., 2019, 'Proactive and reactive models for disaster resilient supply chain', Annals of Operations Research 283(1-2), 199-224. https://doi.org/10.1007/s10479-017-2681-2

Essers, D., 2013, 'Developing country vulnerability in light of the global financial crisis: Shock therapy', Review of Development Finance 3(1), 61-83. https://doi. org/10.1016/j.rdf.2013.02.001

Fitzsimmons, A. \& Atkins, D., 2017, Rethinking reputational risk: How to manage the risks that can ruin your business, viewed 25 April 2020 from https://scholar. google.com/scholar?hl=en\&as $s \mathrm{dt}=0 \% 2 \mathrm{C} 5 \& \mathrm{q}=\% 22$ definition+of+reputational $+\mathrm{ri}$ sk\%22+AND+\%22Fitzsimmons $\% 22 \&$ btnG $=$

Flatt, S.J. \& Kowalczyk, S.J., 2011, 'Corporate reputation persistence and its diminishing returns', International Journal of Business and Social Science 2(19), 1-10.

Foulds, S., 2013, 'Transportation management outsourcing', Transport World Africa 11(5), 32-34.

Gabbi, G., Pianorsi, M. \& Soana, M.G., 2017, The impact of risk culture on bank reputation, viewed 30 May 2020, from https://link.springer.com/ chapter/10.1007/978-3-319-57592-6_8\#citeas.

Galuchi, T.P.D., Rosales, F.P. \& Batalha, M.O., 2019, 'Management of socioenvironmental factors of reputational risk in the beef supply chain in the Brazilian Amazon region', International Food and Agribusiness Management Review 22(2), 155-171. https://doi.org/10.22434/IFAMR2018.0004

Gatzert, N., 2015, 'The impact of corporate reputation and reputation damaging events on financial performance: Empirical evidence from the literature', European Management Journal 33(6), 485-499. https://doi.org/10.1108/JRF-09 2015-0083

Gatzert, N. \& Schmidt, J., 2015, 'Supporting strategic success through enterprise-wide reputation risk management', The Journal of Risk Finance 17(1), 26-45. https:// doi.org/10.1108/JRF-09-2015-0083

Gaudenzi, B., Confente, I. \& Christopher, M., 2015, 'Managing reputational risk: Insights from an European survey', Corporate Reputation Review 18(4), 248-260. https://doi.org/10.1057/crr.2015.16
Gentles, S.J., Charles, C., Ploeg, J. \& McKibbon, K., 2015, 'Sampling in qualitative research: Insights from an overview of the methods literature', The Qualitative Report 20(11), 1772-1789. https://doi.org/10.46743/2160-3715/2015.2373

Gereffi, G. \& Luo, X., 2015, 'Risks and opportunities of participation in global value chains', Journal of Banking and Financial Economics 2(4), 51-63. https://doi. org/10.7172/2353-6845.jbfe.2015.2.4

Gerschel, E., Martinez, A. \& Mejean, I., 2020, 'Propagation of shocks in global value chains: The Coronavirus case', Notes IPP 1(1), 2-9.

Glendon, L. \& Bird, L., 2013, 5th annual survey supply chain resilience 2013, viewed 12 April 2020, from https://www.zurich.co.nz/content/dam/marine/supply-chainsurvey-report-2013.pdf.

Grace, M.F., Leverty, J.T., Phillips, R.D. \& Shimpi, P., 2015, 'The value of investing in enterprise risk management', The Journal of Risk and Insurance 82(2), 289-316. https://doi.org/10.1111/jori.12022

Grant, D., Juga, J., Juntunen, J. \& Juntunen, M., 2014, 'Investigating brand equity of third party service providers', Journal of Services Marketing 28(3), 214-222. https://doi.org/10.1108/JSM-06-2012-0104

Havenga, J.H., De Bod, A. \& Simpson, Z.P., 2016, 'A logistics barometer for South Africa: Towards sustainable freight mobility', Journal of Transport and Supply Chain Management 10(1), 1-7. https://doi.org/10.4102/jtscm.v10i1.228

He, J., 2013, 'Sequential price and quantity decisions under supply and demand risks', International Journal of Production Economics 141(2), 541-551. https://doi. org/10.1016/j.ijpe.2012.09.010

He, J., Alavifard, F., Ivanov, D. \& Jahani, H., 2019, 'A real-option approach to mitigate disruption risk in the supply chain', Omega 88(1), 133-149. https://doi. org/10.1016/j.omega.2018.08.008

Heckmann, I., Comes, T. \& Nickel, S., 2015, 'A critical review on supply chain risk: Definition, measure and modelling', Omega 52(1), 119-132. https://doi. org/10.1016/j.omega.2014.10.004

Hoejmose, S.U., Roehrich, J.K. \& Grosvold, J., 2014, 'Is doing more doing better? The relationship between responsible supply chain management and corporate reputation', Industrial Marketing Management 43(1), 77-90. https://doi. org/10.1016/j.indmarman.2013.10.002

Hohenstein, N.O., Feisel, E. \& Hartmann, E., 2015, ,Research on the phenomenon of supply chain resilience: A systematic review and paths for further investigation', International Journal of Physical Distribution \& Logistics Management 45(1/2) 90-117. https://doi.org/10.1108/IJPDLM-05-2013-0128

Holzhauer, K., 2016, 'Managing supply chain risks and disruptions at an inland terminal with a focus on inter-organizational collaboration challenges', MSc thesis, Delft University of Technology, Delft, The Netherlands, viewed 12 April 2020, from https://repository.tudelft.nl/islandora/object/uuid\%3A2cea9aa52020, from https://repository.

Horn, I.S., Taros, T., Dirkes, S., Hüer, L., Rose, M., Tietmeyer, R., et al., 2015, 'Business reputation and social media: A primer on threats and responses', Journal of Direct, Data and Digital Marketing Practice 16(3), 193-208. https://doi.org/10.1057/ dddmp.2015.1

Isaacs, A.N., 2014, 'An overview of qualitative research methodology for public health researchers', International Journal of Medicine and Public Health 4(4), 318-323. https://doi.org/10.4103/2230-8598.144055

Ivanov, D. \& Dolgui, A., 2020, 'Viability of intertwined supply networks: Extending the supply chain resilience angles towards survivability', International Journal of Production Research 58(10), 2904-2915. https://doi.org/10.1080/00207543.202 0.1750727

Iwu-Egwuonwu, R.C., 2011, 'Corporate reputation \& firm performance: Empirical literature evidence', International Journal of Business and Management 6(4), 197-206. https://doi.org/10.5539/ijbm.v6n4p197

Jakob, C.K., 2012, 'The impact of financial crisis on corporate social responsibility and its implications for reputation risk management', Journal of Management \& Sustainability 2(1), 259-272. https://doi.org/10.5539/jms.v2n2p259

Jüttner, U., Peck, H. \& Christopher, M., 2003, 'Supply chain risk management: outlining an agenda for future research', International Journal of Logistics: Research and Applications 6(4), 197-210.

Kamalahmadi, M. \& Parast, M.M., 2016, 'A review of the literature on the principles of enterprise and supply chain resilience: Major findings and directions for future research', International Journal of Production Economics 171(Part 1), 116-133. https://doi.org/10.1016/j.ijpe.2015.10.023

Karrapan, C., Sishange, M., Swanepoel, E. \& Kilbourn, P.J., 2017, 'Benchmarking criteria for evaluating third-party logistics providers in South Africa', Journal of Transport and Supply Chain Management 11(1), 1-10. https://doi.org/10.4102/ jtscm.v11i0.305

Kim, H., Youn, S. \& Lee, D., 2019, 'The effect of corporate social responsibility reputation on consumer support for cause-related marketing', Total Quality \& Business Excellence 30(5), 682-707. https://doi.org/10.1080/14783363.2017.133 2482

Klibi, W., Martel, A. \& Guitouni, A., 2010, 'The design of robust value creating supply chain networks: A critical review', European Journal of Operational Research 203(2), 283-293. https://doi.org/10.1016/j.ejor.2009.06.011

Kunitsyna, N., Britchenko, I. \& Kunitsyn, I., 2018, 'Reputational risk, value of lossesand financial stability of commercial banks', The International Journal of Entrepreneurship and Sustanability Issues 5(4), 943-957. https://doi.org/10.9770/ jesi.2018.5.4(17)

Larson, P.D. \& Gammelgaard, B., 2001, 'Logistics in Denmark: A survey of the industry', International Journal of Logistics: Research and Applications 4(2), 191-206. https://doi.org/10.1080/13675560110059984 
Lemke, F. \& Petersen, H.L., 2013, 'Teaching reputational risk management in the supply chain' Supply Chain Management: An International Journal 18(4) supply Chain', Supply Chain Management: An Intern

Liamputtong, P., 2013, Qualitative research methods, 4th edn., Oxford University Press, Victoria.

Lietz, C. \& Zayas, L.E., 2010, ,Evaluating qualitative research for social work practitioners', Advances in Social Work 11(2), 188-202. https://doi.org/10.18060/589

Lincoln, Y.S. \& Guba, E.G., 1985, Naturalistic inquiry, Sage, Beverly Hills, CA.

Lloyd, S., 2011, 'Applying the nominal group technique to specify the domain of a construct', Qualitative Market Research: An International Journal 14(1), 105-121. https://doi.org/10.1108/13522751111099346

Markova, O.V., Zavalko, N.A., Kozhina, V.O., Panina, O.V. \& Lebedeva, O.Y., 2018 'Enhancing the quality of risk management in a company', Espacios 39(48), 1-26.

McCorkindale, T. \& DiStaso, M.W., The role of influencers: An analysis of social media discussion across platforms through a sustained crisis, viewed 01 May 2020, from https://books.google.co.za/books?hl=en\&lr=\&id=rAgqDwAAQBAJ\&oi=fnd\&pg=P A374\&dq $=$ McCorkindale $+\% 26+$ DiStaso \&ots $=\mathrm{Kh} 1 \mathrm{BipwBr} 3 \&$ sig $=6 \mathrm{KbcOX}$ OHZWAtq-QAd_WHHNKIp0\&redir_esc $=\mathrm{y} \# \mathrm{v}=$ onepage $\& \mathrm{q}=$ McCorkindale $\% 20$ $\% 26 \% 20$ Distaso $\& f=$ false.

Meyer, A., Niemann, W., Uys, G. \& Beetge, D., 2019, 'An exploration of supply chain risk management in the South African third-party logistics industry', Acto Commercii 19(1), 1-13. https://doi.org/10.4102/ac.v19i1.612

Milne, J. \& Oberle, K., 2005, 'Enhancing rigor in qualitative description', Journal of Wound Ostomy \& Continence Nursing 32(6),413-420. https://doi. org/10.1097/00152192-200511000-00014

Mithun Ali, S. \& Nakade, K., 2014, 'Scenario-based supply chain disruptions management framework: A quantitative approach', Innovation and Supply Chain Management 8(3), 81-91. https://doi.org/10.14327/iscm.8.81

Morgan, B., 2018, 'Managing catastrophic risks in franchise systems', Franchise Law Journal 38(2), 207-225.

Nel, J., De Goede, E. \& Niemann, W., 2018, 'Supply chain disruptions: Insights from South African third-party logistics service providers and clients', Journal of Transport and Supply Chain Management 12(1), 1-12. https://doi.org/10.4102/jtscm.v12i0.377

Niemann, W., Meyer, A., Kotzé, T. \& Odendaal, J., 2018, 'The role of third party logistics providers as orchestrators in emerging markets', Paper Presented at Twelfth Annual International Business Conference, Mauritius, 23rd-26th September, pp. 743-1764, viewed 15 March 2020, from https://www.researchgate.net/profile/ Wesley Niemann/publication/330513194_THE_ROLE_O:F_THIRD_PARTY Wesley_Niemann/publication/330513194 THE_ROLE_O:F_THIRD_PARTY LOGISTICS PROVIDERS AS ORCHESTRATORS IN_EMERGING_MARKETS/
links/5c4577b992851c22a384a282/THE-ROLE-OF-THIRD-PARTY-LOGISTICSPROVIDERS-AS-ORCHESTRATORS-IN-EMERGING MARKETS.pdf.

Oke, A. \& Gopalakrishnan, M., 2009, 'Managing disruptions in supply chains: A case study of a retail supply chain', International Journal of Production Economics study of a retail supply chain, /nternational Journal of Prod

Patton, M.Q., 2015, Qualitative research \& evaluation methods: Integrating theory and practice, 4th edn., Sage, Upper Saddle River, NJ.

Paul, S.K., Sarker, R. \& Essam, D., 2018, 'A reactive mitigation approach for managing supply disruption in a three-tier supply chain', Journal of Intelligent Manufacturing 29(7), 1581-1597. https://doi.org/10.1007/s10845-016-1200-7

Petersen, H.L. \& Lemke, F., 2015, 'Mitigating reputational risks in supply chains', Supply Chain Management: An International Journal 20(5), 495-510. https://doi. org/10.1108/SCM-09-2014-0320

Polit, D.F. \& Beck, C.T., 2012, Nursing research: Generating and assessing evidence for nursing practice, 9th edn., Lippincott Williams \& Wilkins, Philadelphia, PA.

Porterfield, T.E., Macdonald, J.R. \& Griffis, S.E., 2012, 'An exploration of the relational effects of supply chain disruptions', Transportation Journal 51(4), 399-427. https://doi.org/10.5325/transportationj.51.4.0399

Prakash, S., Soni, G. \& Rathore, A.P.S., 2017, 'A critical analysis of supply chain risk management content: A structured literature review', Journal of Advances in Management Research 14(1), 69-90. https://doi.org/10.5325/transportationj. 51.4.0399

Rebs, T., Brandenburg, M., Seuring, S. \& Stohler, M., 2018, 'Stakeholder influences and risks in sustainable supply chain management: A comparison of qualitative and quantitative studies', Business Research 11(1), 197-237. https://doi.org/10.1007/ s40685-017-0056-9
Reese, C.L. \& Kossovsky, N., 2011, 'Intangibles and the new reality: Risk, reputation, and value creation', Corporate Finance Review 16(1), 20-32.

Revilla, E. \& Saenz, M.J., 2017, 'The impact of risk management on the frequency of supply chain disruptions: A configurational approach', International Journal of Operations \& Production Management 37(5), 1-34. https://doi.org/10.1108/ IJOPM-03-2016-0129

Roehrich, J.K., Grosvold, J. \& Hoejmose, S.U., 2014, 'Reputational risks and sustainable supply chain management: Decision making under bounded reality', International Journal of Operations and Production Management 34(5), 695-719. https://doi. org/10.1108/IJOPM-10-2012-0449

Sáenz, M.J., Revilla, E. \& Acero, B., 2018, 'Aligning supply chain design for boosting resilience', Business Horizons 61(3), 443-452. https://doi.org/10.1016/j. bushor.2018.01.009

Samvedi, A., Jain, V. \& Chan, F.T.S., 2013, 'Quantifying risks in a supply chain through integration of fuzzy AHP and fuzzy TOPSIS', International Journal of Production Research 51(8), 2433-2442. https://doi.org/10.1080/00207543.2012.741330

Sanchez Rodrigues, V., Harris, I. \& Mason, R., 2015, 'Horizontal logistics collaboration for enhanced supply chain performance: An international retail perspective' Supply Chain Management: An International Journal 20(6), 631-647. https://doi. org/10.1108/SCM-06-2015-0218

Scholten, K., Sharkey Scott, P. \& Fynes, B., 2014, 'Mitigation processes: Antecedents for building supply chain resilience', Supply Chain Management: An International Journal 19(2), 211-228. https://doi.org/10.1108/SCM-06-2013-0191

Shenton, A.K., 2004, 'Strategies for ensuring trustworthiness in qualitative research projects', Education for Information 22(2), 63-75. https://doi.org/10.3233/EFI2004-22201

Sheffi, Y., 2015, 'Preparing for disruptions through early detection', MIT Sloan Management Review 57(1), 31-42.

Soppe, A., Schauten, M., Soppe, J. \& Kaymak, U., 2011, 'Corporate social responsibility reputation (CSRR): Do companies comply with their raised CSR expectations?', Corporate Reputation Review 14(4), 300-323. https://doi.org/10.1057/ crr.2011.21

Stefansson, G., 2006, 'Collaborative logistics management and the role of third-party service providers', International Journal of Physical Distribution \& Logistics Management 36(2), 76-92. https://doi.org/10.1108/09600030610656413

Szwajca, D., 2018, 'Dilemmas of reputational risk management: Theoretical study', Corporate Reputation Review 21(1), 165-178. https://doi.org/10.1057/s41299018-0052-9

Tannous, K.A. \& Yoon, S., 2018, 'Summarizing risk, sustainability and collaboration in global supply chain management', International Journal of Supply and Operation Management 5(2), 192-196.

Tukamuhabwa, B., Stevenson, M. \& Busby, J., 2017, 'Supply chain resilience in a developing country context: A case study on the interconnectedness of threats, strategies and outcomes', Supply Chain Management: An International Journal 22(6), 486-505. https://doi.org/10.1108/SCM-02-2017-0059

Tukamuhabwa, B., Stevenson, M., Busby, J. \& Zorzini, M., 2015, 'Supply chain resilience: Definition, review and theoretical foundations for further study', International Journal of Production Research 53(18), 5592-5623. https://doi.org/ 10.1080/00207543.2015.1037934

Vanhamme, J. \& Grobben, B., 2009, “"Too good to be true”: The effectiveness of CSR history in countering negative publicity', Journal of Business Ethics 85(1), 273-283. https://doi.org/10.1007/s10551-008-9731-2

Verbano, C. \& Venturini, K., 2013, 'Managing risks in SMEs: A literature review and research agenda', Journal of Technology Management \& Innovation 8(3), 186-197. https://doi.org/10.4067/S0718-27242013000400017

Waugh, B. \& Luke, R., 2011, 'Logistics outsourcing by manufacturers in South Africa', Journal of Transport and Supply Chain Management 5(1), 337-360. https://doi. org/10.4102/jtscm.v5i1.81

Wikner, J. \& Bäckstrand, J., 2018, 'Triadic perspective on customization and supplier interaction in customer-driven manufacturing', Production \& Manufacturing Research 6(1), 3-25. https://doi.org/10.1080/21693277.2017.1415825

Wu, T., Huang, S.M., Blackhurst, J., Zhang, X.L. \& Wang, S.S., 2013, 'Supply chain risk management: An agent-based simulation to study the impact of retail stockouts', IEEE Transactions on Engineering Management 60(4), 676-686, https://doi. org/10.1109/TEM.2012.2190986 